\title{
Universal old-age pension: Can Africa overcome it's challenges?
}

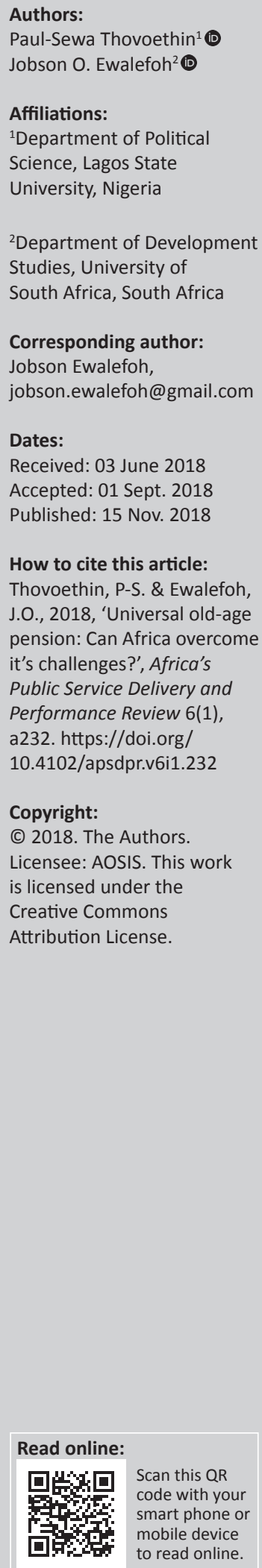

Background: Social security is an important human right recognised in several international legal instruments and by non-state actors and most countries of the world. In Africa, as a result of the increasing number of aged people in most countries, the need to implement social security in the form of old-age pension schemes and workers' compensation remains compelling.

Aim: The aim of this article is to examine the nature of old-age pension in selected countries in Africa.

Setting: The article takes a critical look at the nature of old-age pension schemes in some African countries. It observes that while most countries in the global north take social security seriously especially as it relates to the aged, in most countries on the continent of Africa, social security schemes are taken for granted.

Methods: The article is qualitative in nature, it relies on secondary sources of data.

Results: The findings shows that the implementation of old-age pension and workers compensation are especially taken for granted in most countries in Africa with the exception of South Africa that has old age pension shemes for both formal amd informal sectors.

Conclusion: It concludes that the implementation and management of social security systems require quite complex institutions which, again, are not available in most of these countries.

\section{Introduction}

The world population has increased rapidly and aged since the beginning of the 21st century. The number of older persons in most countries is increasing (United Nayions 2017). The situation as noted by the United Nations (2017) has become one of the most critical social transformations. It is projected that about two billion people are expected to be over 60 years by the year 2050 (World Health Organisation 2017). This shows that the number of people above 60 years has increased when compared with the number of young people in most countries of the world (United Nations 2017). As observed by the United Nations (2016), the number of older persons in Africa has doubled since 1990, and it is estimated to be more than triple between 2015 and 2050. For instance, in sub-Saharan Africa, as of 1990 there were 23 million people 60 years and above, this increased to 46 million people in 2015. In 2050, a projected 161 million older persons will be residing in Africa (United Nations 2016). Because of such increase, in almost every country in the world, there exist fiscal policies involving income redistribution to address the challenges facing the old people of the population.

In Africa, as a result of the increasing number of aged people in most countries, the need to implement social security in the form of old-age pension schemes and workers' compensation remains compelling. In the developed societies, social security is an essential human right recognised by international organisations through their legal instruments. One of the critical challenges that are confronting most African countries, except South Africa which genuinely has a universal pension system, is how to ensure adequate income to older people without its effect on the nation's economies and the younger generations. It is instructive to observe that at the moment, African countries have various pension schemes to protect their citizens against old-age poverty. However, most of these pension schemes in practice lack comprehensiveness regarding the people and the capability to offer benefits and adequate services (Bloom \& McKinnon 2013). The implication of this on the attainment of Sustainable Development by 2030 by the eradication of poverty in Africa depends on recognising and addressing the insecurity of old-age income by central governments (UNDESA 2016).

Against this backdrop, it shows that there is the need for an increased interest by African countries in social security measures, especially in the area of pension schemes. Thus, steps must be taken 
to address the challenges of social security by countries in Africa by extending the scheme to the informal sector of the society. Therefore, this article is a response to the compelling need to address the challenges of pension schemes in Africa. To achieve the main thrust of article, it is pigeon-holed into four sections. The first section does an analysis of pension schemes in Africa before dwelling into a comparative study of pension schemes in Africa and global north. The next section is devoted to an examination of the various challenges of pension schemes in Africa, which is followed by the section for recommending solutions to these challenges. The article ends with some concluding remarks.

\section{Social security in Africa: An assessment}

In some African countries such as South Africa, Egypt, et cetera some form of pension and social security system is available for the older people. For instance, in South Africa, old-age pension is provided even to those who were not in formal employment, while countries like Nigeria do not have a sustainable social security system. Even the 2004 pension scheme introduced in Nigeria for those in employment mostly in the public sector is still at the infant stage, which is still facing some challenges in its implementation. This implies that in Nigeria and some African countries, benefits are offered to formal sector workers. This goes to show that in many countries in Africa, pension schemes only cover the formal sector of the economy, whereas most people are working in the informal sector without adequate pension scheme. This shows that this category of people rely on informal arrangements and their family resources (Stewart \& Yermo 2009). This position would be justified with an assessment of different pension schemes in some African countries to confirm the various levels of overall coverage of these schemes as well as the effective implementation of the schemes. The pension schemes in most African countries are contributory and non-contributory pension schemes, while in most developed societies, general taxation is the major source of funding for the non-contributory pension scheme, unlike the situation in most African countries which places a financial burden on the government in financing the payment of social security (Pelham 2007).

South Africa was the first state in Africa to institute pension schemes (Pelham 2007). More so, most countries on the continent are reforming their pension schemes. The primary element of these reforms centres on the need to improve the effectiveness and quality of the somewhat ineffective pension system in these countries. Having established these two positions on social security in Africa, attempts would be made to assess pension schemes in some selected African countries.

In 1996, an old-age social security scheme known as ‘Universal Old Age Pension System' was inaugurated in Botswana. According to Stewart and Yermo (2009), the scheme extends its coverage to citizens aged more than 65 years, while the burden of financing the scheme was borne by the government (United States Department of Agriculture 2018). Also, there is gratuity or severance scheme in which employers are expected to make a cash payment immediately to an employee who spends 5 years on the job, at the end of every 5 years after that, with entitlement for pro-rata cash assistance on termination of appointment. It is important to state that under this system, employers of labour are not expected to pre-fund these obligations.

In Cape Verde, the pension schemes are two-fold for employees in the formal sector. These include the Administração Públical (AP) and the Instituto Nacional de Previdência Social (INPS). (Stewart \& Yermo 2009). The INPS was launched by the National Social Security Institute in 1983 to administer a mandatory social security scheme. It was intended to be selffinancing by investments and social contributions. However, the state shoulders the responsibility of adequate and responsible administration through the provision of benefits to the people concerned.

It should be noted that both schemes cover only one-quarter of the labour force in Cape Verde. It is important to state that the AP as a pension scheme is more generous than the INPS. The AP has a retirement age of 55 years for police and teachers; the retirement age for others workers is 60 years. In the case of INPS, the retirement age varies for men and women; men are expected to retire at 65 years while women are expected to retire at 60 years (Stewart \& Yermo 2009). This is because teachers and the police constitute almost half of the civil servants in Cape Verde.

Moreover, for the AP, 1 year is considered for the wage base calculations for old-age and involuntary retirement. In the case of INPS, calculation is done for 10 years for old-age, while it is 5 years for invalid people. Furthermore, aside from the AP and INPS, there are other non-contributory pension schemes. These include The Pensão de Solidaridadell, paid to workers aged more than 60 years and is subject to a (vague) income test and the workers must have worked for a minimum of 10 years under the scheme. There is also the Pensão Social Mínimal (PSM). The PSM is a social security assistance scheme established under a 1995 law that pays benefits and entitlements to older people who meet the age and income criteria (Stewart \& Yermo 2009).

In Gambia, the nature of pension as observed by Saliu (2014) includes the Public Service Pension Scheme. This scheme basically covers public officials (both uniformed services and civil servants) (Saliu 2014). Most of the employees in the formal sector participate in compulsory pension schemes. Though these schemes share similar features, it is important to note that there is no mechanism to facilitate movement of employees and the movability of accrued rights between schemes in the public sector (Saliu 2014:23). In the case of Kenya, Stewart and Yorme (2009) in their study revealed that the retirement benefit schemes in Kenya comprise the civil service scheme, occupational scheme, 
National Social Security Fund (NSSF) and individual pension schemes. The employee contributes 5\%, while employees contribute $5 \%$ of their monthly incomes. In the informal sector, the self-employed contribute $5 \%$ of their monthly income. For the informal sector, there is no minimum or maximum contribution to the scheme. This was later adjusted to enable members of NSSF to increase their savings with any amount that is not below KSh 1000 . Also, the old-age pension scheme is for employees aged 55 years and above who have retired from employment covered by the scheme (Stewart \& Yorme 2009).

In Nigeria, before the commencement of the present regime of the contributory pension scheme, the existing pension scheme was the defined benefit scheme, which was basically in a state of uncertainty. The scheme was underfunded or unfunded; it was a weak and inefficient pension system; most employees in the private and informal sector were not covered by any form of retirement benefits or pension scheme, and cases of unmanageable, unsustainable, unpaid pension liabilities were predominant. The outstanding pension liabilities of the government of Nigeria at the start of the Pension Reform Act (PRA) in 2004 was valued to be around $\mathrm{N} 2$ trillion. Financial predictions then projected that in a few years, pension obligations would surpass the remuneration of active workers. The pension obligation was an economic menace waiting to happen, and its predictions were not encouraging. The difficulties associated with the old scheme resulted in the introduction of the new pension scheme through the Pension Reform Act of 2004 during Obasanjo's administration (Nwanne 2015; Odia \& Okoye 2012). The scheme is a contributory and fully funded and is privately managed by the pension fund administrator. This shows that the nature of the pension scheme in Nigeria is basically for those in formal employment (most public institutions). The scheme is funded through monthly contributions by both employee and employer (Kotun, Adeoye \& Alaka 2016). Both parties (employee and employer) are expected to contribute on a monthly basis a minimum of $7.5 \%$ to the employee's pension fund (and the employer alone can bear the burden of contributing at least $15 \%$ of an employees salary to the pension fund). The case is different in the armed forces, while the employee (armed forces personnel) contributes $2.5 \%$, the government is expected to contribute $12.5 \%$ (2.5\%) (Omoni 2013; Ozor 2006). The contributory pension scheme is compulsory for all employees in the public sector (except diplomats) and for private sector organisations employing a minimum of five workers or more (Stewart \& Yorme 2009). The new pension scheme is guided by the important principles of equity, sustainability, flexibility, practicability and accountability (Uzoh \& Anekwe 2018).

The 2014 amended Pension Act extended its coverage to the private sector organisations with at least five employees. The amended act increased the minimum contribution from $15 \%$ to $18 \%$ of monthly earnings. Out of this, employees are expected to contribute $8 \%$ while employers will be contributing 10\% (Eme, Uche \& Uche 2014). The amended act provides additional benefits to employees Retirement
Savings Accounts, thereby increasing their monthly pension benefits when they retired.

It is necessary to stress the fact that Nigeria is the first country in Africa to introduce a 'Chilean Style' pension system (National Pension Commission 2005). Having adopted the Chilean style' individual funded accounts by Nigeria, it is necessary to state that the implementation of the scheme has been plagued by the lack of infrastructure to support the operation of the system, absence of records, institutional financial capacity and market development. Moreover, just like most countries on the continent, the majority of individuals in Nigeria work in the informal sector, and therefore, the scheme is unable to provide formal social security programmes to Nigerians.

The first country to institute a pension scheme is South Africa. Though the first pension scheme started in 1882, it was not supported by any law until 1920 when the government established occupational retirement insurance (National Treasury 2007). Unlike other African countries, the pension scheme in South Africa is quite an extensive social security pension scheme (Barrientos 2004; van der Berg, Siebrits \& Lekezwa 2011). South Africa has a means-tested, social grant (The state Old-Age Grant [SOAG]) for over 75\% of people of retirement age and well-developed private retirement savings and occupational pension system (Devereux 2001). Though the old pension system in South Africa is means-tested, it is almost universal because most older adults are too poor to be excluded from the scheme (Ferreira 1999:55). The public pension scheme in South Africa provides a non-contributory, means-tested old-age pension, while finance from general revenues is used to finance the old-age pension system. The pension is payable to South Africans who are 60 years old (available at https: / / www.gov.za/services/social-benefits-retirement-and-oldage/oldagepension).

Benefits accrued to a pensioner is up to R940 a month, while married couples may receive about R1880 per month. In the private sector, pensioners who are a resident for more than 3 months is reduced to $25 \%$ of the full amount (Stewart \& Yorme 2009).

South Africa has a three-component retirement pension system. The first component is what is called a contributory employment-related pension fund. The second component is private savings, and the third component is the social assistance programme called the state Old Age Pension (van Zyl 2003). In South Africa, however, a vast number of people not working in the formal sector and hence are not covered by the insurance-based pension. This is estimated at $67 \%$ of the population (Burns, Malcolm \& Murray 2005). This, in the views of Case and Angus (1998) shows that the adopting of age-based tageting is successful in South Africa.

From the analysis of the social security of some countries in Africa, it is evident that apart from South Africa, Botswana and Mauritius, informal pension schemes or other social 
security schemes are not available. Even when available, they pay insignificant benefits and cover only a small proportion of the older people population. In most of the countries in Africa where there is some form of social security coverage by statutory social security schemes (Gillian et al. 2000; Stewart \& Yorme 2009), it is very limited to employees in the formal sector of the economy and their families. Therefore, the majority of the elderly are at the sympathy of nature and human forces. This is tragic against the backdrop of the fact that the traditionally collective solidarity practice in Africa of the ethnic group, clan and extended family, which used to be the backbone of social security and income in most African countries are fast disappearing.

\section{Universal old-age pension scheme in the global north and Africa: Explaining the variation}

Analysis of social security in the global north and Africa justifies the fact that social security is more effective, with a broader coverage in the global north than in Africa. The International Labour Office (2015) shows that in sub-Saharan Africa, only $16.9 \%$ of older people receive old-age pension. Bloom \& McKinnon (2013) underscore this when they posit that the degree of the problems of old-age pension varies widely. According to them:

\begin{abstract}
At one extreme are industrial countries, in most cases Organisation for Economic Co-operation and Development members, where social security provision is typically both comprehensive (with provisions for old-age, disability, survivorship, maternity, work injury and occupational diseases, unemployment, family allowances, medical benefits, and for a small but growing number of countries, long-2 term care) and universal (ostensibly covering 100 per cent of the target population). At the other extreme are lower-income countries in sub-Saharan Africa and South Asia where coverage may extend to less than 10 per cent of the population and handle only a limited number of contingencies (e.g. old-age, disability, survivorship, and work injury). In the middle are a majority of countries, where risk coverage is at the intermediate level, as is the proportion of the population with access to such protection (Bloom \& McKinnon 2013:1-2 quoting ILO 2010).
\end{abstract}

Upon the backdrop of this position, what is of utmost importance and which this section intends focusing on is the assessment of the reasons for these discrepancies in the coverage and implementation of social security in the global north and Africa. While most countries in the global north take social security seriously, especially as it relates to the aged, most countries on the continent of Africa take social security schemes for granted. The implementation of old-age pension and workers compensation is taken for granted in most countries in Africa; this is because most of the countries are facing serious budget challenges, making it difficult for them to finance the social security schemes.

Worthy of emphasising and as also pointed out in the preceding section is that for many years, most countries in Africa relied on traditional measures for the support and care of elderly people (Dorfman 2015; Kaseke 2003; 2013; Kaseke \& Olivier 2010; Odundo \& Ouma 2018). Until recently, the family is the most crucial basis of income for the older people in Africa than somewhere else in developing societies. The informal systems in Africa are based on broader familiar links than in countries in the global north. The extended family could accommodate adult brothers and sisters as well as children. In most of the countries in Africa, dependency on the younger generation is not limited to the nuclear family alone. The practice of fosterage, adoption, extended family and raising grandchildren, all contributed to widening the support base. The community, kin and tribal support is another source of informal support in Africa (World Bank 1994). shows that the continued relevance of these conventional arrangements for the support and care of older people has reduced because of changes in the value system as a result of modernisation, globalisation and development (Cohen 2006; Kaseke 2013; Odundo \& Ouma 2018). Therefore, these changes more than ever before place the responsibilities for taking care of the older people on the government, which in the first place did not see that as their responsibility. Invariably, adequate focus has not been given to social security by most of the countries on the continent because most of them did not see this as a priority (Cohen 2006; Messkoub, 2009).

Furthermore, Bloom and McKinnon (2013), quoting McCord (2010), underscore the fact that most countries in Africa have the challenge of coping with the political economy of pension schemes, hence their reluctance to implement those schemes. According to Bloom and McKinnon (2013), old-age pension programmes involve a component of redistribution (i.e. transfer of resources from the rich to the poor and from 'more productive' younger people to 'less productive' older people in the society). This resulted in a 'winners' and 'losers' situation, in the sense that an individual may contribute more or less than another in the financing of pensions applicable to the amount they are actuarially due or receive (Bloom \& McKinnon 2013; Ghellab, Varela \& Woodall 2011).

Another political economy concern is the context of administrative capacities and limited financial resources in most African countries. This is premised on the fact that the choice to spend more on an old-age pension programme comes at the cost of having to channel expenditure away from other equally essential needs (Bloom \& McKinnzon 2013; McCord 2010). The Department of Economic and Social Affairs programme on ageing emphasises this position by positing that sustainable pension schemes remain a considerable task for more developed countries, particularly as some governments seek to find cost-savings measures through reforms in public pension schemes as part of financial consolidation policies. According to the report, these undermine the capability of pension systems and therefore reduce their ability to check poverty in old-age.

Devereux and White (2010) also explain that in most countries in Africa, the implementation of social security has become 
problematic when compared to the global north. According to them, the challenges include the fact that most of the African countries face severe budget challenges, making it almost challenging to finance the social security schemes. Besides, adequate implementation of social security schemes requires quite well-established and organised institutions which, again, are not present in most of these countries. Devereux and White (2010) conclude their position in their analysis of challenges confronting the implementation of social security in Africa by categorically stating the fact that the increased rate of underemployment and unemployment, as well as the incapability of current social protection standards, affect effective delivery of social security in many countries in Africa (International Labour Organisation 2016).

\section{Addressing the challenges of pension schemes in Africa}

This section intends to achieve three fundamental objectives. The first objective is to look at options available for African governments to extend the total coverage of pension schemes. The second objective is to examine how to make social security schemes to be more effective in Africa. The third aim is to look for ways of achieving these two objectives without unnecessarily increasing the financial burdens or budgetary strains on African governments, especially considering the lack of funds in most of these countries. However, before examining ways through which these objectives could be achieved, it is essential to raise the caveat that social security in Africa might not be the same with the social security schemes in the global north. Leisering (2010) has argued within this context when he asserts that policy learning is not usually a process of copying models from other countries. According to him, institution building depends on the social conditions given in a country, and apparently, circumstances in developing countries differ markedly from developed countries. More so, it is imperative to state that all countries in Africa cannot implement uniform pension schemes. Therefore, attention under this section shall be focused on both formal and informal relevant mechanisms in some countries in the global north and some specific African countries that could guarantee the future of older people albeit at lower cost, which could be adopted by various African countries depending on the peculiarities in each country.

As indicated in the above paragraph, the take-off point of the analysis under this section is how best social security coverage could be extended in Africa, to improve the wellbeing of the people, especially in the area of old-age pensions. As Sigg (2003) suggests, there is a need for effective social safety nets, through the establishment of basic universal or means-tested, tax-financed old-age pensions that can be of help in preventing poverty for the people with no means of livelihood and contributing to the scheme. Sigg (2003) further suggests three possibilities for extending the social security coverage to other countries in Africa. These can be linked to occupation-based insurance, pluralistic national social security systems or building community-based insurance schemes on collective bargaining basis or voluntary and introducing primary tax-financed benefit systems. This can be done through a non-contributory scheme such as universal social pensions and tax-financed cash transfers (International Labour Organisation 2016).

Dorfman (2015) in his view suggests institutional support and increased coverage with multiple revisions in design and implementation. Compulsory contributory schemes could be extended to small organisations and the self-employed so that low-income earners and small organisations can participate with affordable contribution rates. He states further that social assistance to older people through broadbased household programmes should be considered for those facing destitution or poverty in old-age.

To improve the adequacy and coverage of the old-age pension scheme in Africa, there is a need for strengthening voluntary savings arrangements. Such provisions in the opinions of Bloom and McKinnon (2013) could complement compulsory schemes or could form the basis for contributory old-age income protection. Also, the following option as suggested by Bloom and McKinnon (2013) will be of immense importance to the successful implementation of the scheme. This includes reforming regulatory framework and adequate supervision; ensuring transparency in implementation; state support in the form of matching contributions to improving encouragements for retirement savings; state support for leading and testing with new voluntary pension savings arrangements; well-supervised individual and occupations savings arrangements; and tax incentives or inducements for pension contributions. De Wispelaere and Stirton (2012), while also examining ways of extending social security to informal sector workers, observe logically that this could be achieved through programmes financed by budget, which may provide widespread coverage. This could be accomplished by accurate records keeping and the delivery of benefits to those who are eligible.

Having examined various means of extending social security in Africa, what is also relevant is to look for options for making social schemes more effective. According to Sigg (2003), in addressing the challenge of ageing. Africa countries can adopt the Singapore's model. In Singapore, old people are given recognition in policy-making at the national level. This can be achieved by setting up an interdepartmental committee whose members are drawn from welfare ministries, social security and voluntary organisations. The open and democratic debate is important for the formulation of correct, accurate and legitimate policies. The legitimation issue is needed for the public acceptance and implementation of policies and for maximising donor's assistance.

Another critical area that requires attention when looking at how to make social security more useful in Africa is how to address the challenge posed by the movement of labour. The Nigerian individual capitalised account which allows 
mobility of labour across sectors and the different tiers of government could be a reference point for other countries on the continent that intend on addressing the problems associated with mobility of labour. In Nigeria, once a Retirement Savings Account is opened, and a Personal Identification Number (PIN) is issued to an employee, these numbers are unique to a worker employee throughout a lifetime. Thus, where an employee moves from one job to another, the same individual account is kept for future contributions. The employee just needs to supply the new employer with the name of Pension Fund Administrator and PIN number (Bloom \& McKinnon 2013).

Good governance in Africa is also crucial for good social security and its credibility. According to Bailey (n.d.), if the system fails to deliver it will become problematic to ensure obedience and a spiral of executive failures will follow resulting in general evasion, often effectively ignored by an increasingly ineffective and perhaps depressed administration. Therefore, public-institutionalised social security schemes on the continent need to be based on a sound legislative and administrative structure which respects the roles and responsibilities of the participants: the payer, the receiver and those who are responsible for making the systems work. These features have not been adequately steadily present in social security schemes in Africa, and their absence has led to the administrative weaknesses and ineffective of the schemes.

Reversing the trend towards early retirement is another keystone of any strategy designed to reduce the fiscal liability of social security systems in Africa. Early retirement would be made possible through what McGregor et al. (1998) refers to and as quoted by Thovoethin (2012) as an 'Economic Jumpstart', that is, an incentive for staff to leave the civil service before the normal retirement age and start productive lives that will contribute to the growth and development of the economy. This economic jumpstart is based on a guided chain of activities. The starting point is the training of the public servants leaving service. It would be necessary to know what connections, assets, skills and prospects some workers have. A survey could be carried out to this effect before retirement. This can lead to a better understanding of what the workers intend to do after retirement. Alternatively, the potential retiring workers could be allowed a four-day working week, giving 1 day off and adding one more working hour to each of the remaining four working days. These workers would then be expected to identify or start some economic activity during this transition period in anticipation of severance (Thovoethin 2012). Thus, after retirement, they continue with their chosen economic activities which would also assist the economic development of their country. It should, however, be noted that this suggestion applies to workers with formal employment.

\section{Conclusion}

In this article, it has been established that the danger of poverty in old-age is common in Africa where social protection coverage, especially in the area of the pension scheme, is inadequate or absent than in any other region of the world. Thus, the absence in some countries and the inability to accomplish full coverage with contributory pension systems in most countries bring into focus new thinking in sub-Saharan Africa about alternatives for old-age income protection, particularly for people in the informal sector and agriculture with unstable incomes. Various options for addressing the challenges of old-age pension in Africa have been examined under this work. Those options suggested are those that could assist in closing the coverage gap, which should be a central focus of reforms that could shift to better protection for uncovered workers and retirees in many countries. Thus, more work is needed to ensure that pension schemes in Africa are better associated with the desires of informal and rural workers with insecure and low incomes.

More so, there is also the need to align pensions to a country's needs and enabling conditions. Extending and ensuring a satisfactory level of social security shows a continuously growing process as governments and regulators across the globe need to adapt to changes in the environment that could lead to some profound peculiarities. Therefore, considerable attention is desirable to find the balance between reform designs, incentives and oversight to fit into each country's needs and endogenous conditions. Beyond this, it is imperative to observe that non-contributory support to the older people's needs to be financially sustainable over the long term. This is of utmost importance amidst economic and social pressures and increased longevity and decline of customary family-based support. This implies that policy interventions that would enhance wider coverage and effectiveness of pension schemes must take into cognisance budgetary constraints of most African countries. Invariably, as Dorfman (2015) suggests, options to refund civil servants on contributory pension schemes need to carefully consider enabling conditions, including the financial capacity to support transition costs and the required institutional and regulatory infrastructures.

\section{Acknowledgements Competing interests}

The authors declare that they have no financial or personal relationships which may have inappropriately influenced them in writing this article.

\section{Authors' contributions}

This work was carried out in collaboration between both authors. P-S.T. designed the study and wrote the first draft of the manuscript. J.O.E. managed the literature searches, reviewed the draft manuscript. P-S.T proofread the manuscript. J.O.E updated the article, as well as corrected the work using plagiarism software. J.O.E also made corrections suggested by the reviewers. P-S.T and J.O.E read and approved the final manuscript. 


\section{References}

Bailey, C., n.d., 'Extending social security coverage in Africa', Social Security Policy (SOC POL), Geneva.

Barrientos, A., 2004, Cash transfers for older people reduce poverty and inequality, Draft background paper for WDR 2006: Equity and development, Also published in Pathways of Inequality, World Bank, New York.

Bloom, D. \& McKinnon, R., 2013, The design and implementation of public pension systems in developing countries: Issues and options, Program on the global demography of aging, Working paper No 102, United Nations, New York.

Burns, J., Malcolm, K. \& Murray, L., 2005, 'Social assistance, gender and the aged in South Africa', Feminist Economics 11(2), 103-115. https://doi.org/10.1080/ 13545700500115944

Case, A. \& Angus, D., 1998, 'Large cash transfers to the elderly in South Africa', The Economic Journal 108(September), 1330-1361. https://doi.org/10.1111/14680297.00345

Cohen, B., 2006, 'Ageing in sub-Saharan Africa: Recommendation for furthering research', in B. Cohen, J. Menken (eds.), National research council (US) committee on population, pp. 39-45, National Academies Press, Washington, DC.

De Wisperlaere, J. \& Stirton, L., 2012, 'A disarmingly simple idea? Practical bottlenecks in the implementation of a universal basic income', International Social Security Review 65(2), 103-121. https://doi.org/10.1111/j.1468-246X.2012.01430.x

Devereux, S. 2011, Social Protection in South Africa: Exceptional or Exceptionalism?', Canadian Journal of Development Studies 32(4), 414-425.

Devereux, S. \& White, P., 2010, 'Social Protection in Africa: Evidence, Politics, and Rights', Politics and Public Policy 2(3), 5, 53-77.

Dorfman, M., 2015, 'Pension patterns in Africa', World Bank Group Social Protection and Labour, World Bank, Washington. (Discussion paper no. 105).

Eme, O.I., Uche, O. \& Uche, I.B., 2014, 'Pension Reform Act 2014 and the future of pension administration in Nigeria', Arabian Journal of Business and Management Review (OMAN Chapter) 4(2), 156-166. https://doi.org/10.12816/0019043

Ferreira, M., 1999, South Africa's social pension system: Who benefits and how? Ageing in Changing societies: Africa preparing for the next millennium, Nairobi. (Ages Workshop Report)

Ghellan, Y., Varela, N. \& Woodall, J., 2011, 'Social dialogue and social security governance: A topical ILO perspective', International Social Security Review 64(4), 76-87. https://doi.org/10.1111/j.1468-246X.2011.01410.x

Gillian, C., Turner, J., Bailey, C. \& Latulippe, D., 2000, Social security pensions: Development and reform, International Labour Office, Geneva, Switzerland.

International Labour Office, 2010, International labour conference 100th session: Social security and the rule of law, International Labour Office, Geneva.

International Labour Office, 2015, World social protection report 2014/15. Building economic recovery, inclusive development and social justice, International Labour Office, Geneva.

International Labour Organisation, 2016, Social protection in Africa, viewed 24 February 2018, from http://www.ilo.org/addisababa/areas-of-work/socialprotection/lang--en/index.htm

Kaseke, E. \& Olivier, M., 2008, "Informal Social Security", in M. Olivier and S. Kuhnle (eds.), Norms and Institutional Design: Social Security in Norway and South Africa pp. 175-182.

Kaseke, E., E., 2003, 'Informal social security in Eastern and Southern Africa', Regional Development Studies 9(8), 43-50.

Kaseke, E., 2013, 'Social security in Southern Africa', Paper presented at the SASPEN and FES International Conference on Social Protection for Those Working Informally, Birchwood Hotel, Johannesburg, 16-17th September 2013.

Kotun, A.I., Adeoye, A.O. \& Alaka, N.S., 2016, 'Effects of contributory pension scheme on employees' productivity: Evidence from Lagos state government', African Journal of Business Management 10(16), 384-396. https://doi.org/10.5897/ AJBM2016.8102

Leisering, L., 2010, 'Extending social security to the excluded: Are social cash transfers to the poor an appropriate way of fighting poverty in developing countries?', Global Social Policy 9, 246-272.

Lund, F., 1999, 'Understanding South African social security through recent household surveys: New opportunities and continuing gaps', Development Southern Africa 2(3), 12-19.

McCord, A., 2010, 'The impact of the global financial crisis on social protection in developing countries', International Social Security Review 63(2), 23-31. https:// doi.org/10.1111/j.1468-246X.2010.01360.x
McGregor, H.A., Lieberman, J.D., Greenberg, J., Solomon, S., Arndt, J. \& Simon, L., 1998, 'Terror management and aggression: Evidence that mortality salience motivates aggression against worldview-threatening others', Journal of Personality motivates aggression against worldview-th
and Social Psychology 74(3), 590-605.

Messkoub, M., 2009, Economic growth, employment and poverty in the Middle East and North Africa, Working Paper, no. 460, World Bank, Institute of Social Studies, The Hague.

National Pension Commission, 2005, Frequently asked questions and their answers on the contributory pension scheme in Nigeria, National Pension Commission, Abuja.

National Treasury, 2007, Social security and retirement reform. Second discussion paper, South Africa: National Treasury, Pretoria.

Nwanne, T.F.I., 2015, 'Impact of contributory pension scheme on economic growth in Nigeria', Global Advanced Journal of Management and Business Studies 4(8), 333-337.

Odia, J.O. \& Okoye, A.E., 2012, 'Pension reform in Nigeria: A comparison between the old and the new scheme', Afro-Asian Journal of Social Sciences 3(3), 1-17.

Odundo, E. \& Ouma, S., 2018, 'Rethinking pension inclusion in Kenya', in P. Khana, W. Price \& S. Bhan, (eds.), Saving the next billion from old age poverty: Global lessons for local action, Narosa Publishing House, New Delhi, pp. 45-68.

Omoni, G.E., 2013, 'An overview of the new pension scheme and teachers level of awareness in the Delta state of Nigeria: Counseling complications', African Journal of Social Science 3(3), 53-63.

Ozor, E., 2006, 'Review of factors that slowdown the processing of retirement benefits', A paper presented at the workshop organized by the institute of chartered secretaries and administration of Nigeria, $14-16^{\text {th }}$, May 2006, Lagos, Nigeria.

Pelham, L., 2007, The politics behind the non-contributory old age social pensions in Lesotho, Namibia and South Africa, Chronic Poverty Research Centre (CPRC) Working Paper, Vienna 83, p. 34

Saliu, Y.S., 2014, 'Gambia: Dubai firm partners with SSHFC for housing scheme in the Gambia', The Daily Observer (Banjul), 28 February, 2014, p. 34.

Shankar, S. \& Asher, M., 2011, 'Micro-pensions in India: Issues and challenges', International Social Security Review 64(2), 43-49. https://doi.org/10.1111/ j.1468-246X.2011.01390.x

Sigg, R., 2003, A global overview on social security in the age of longevity. United Nations expert group meeting on social and economic implications of changing population age structure, Population Division Department of Economic and Socia Affairs, New York.

Stewath, F. \& Yermo, J., 2009, Pensions in Africa, OECD working papers on insurance and private pensions 30, Paris, France: OECD Publising.

Thovoethin, P., 2012. 'Privatization of education and the 6-3-3-4 educational system in Nigeria: A critical (re)assessment', Being a Paper Presented at the Open Society Initiative for Southern Africa Organized Conference on Globalization, Regionalization and Privatization in and of Education in Africa, Held at Crowne Plaza Hotel, Johannesburg, South Africa, from 12th-13th October, 2012.

UNDESA, 2016, Income poverty in old age: An emerging development priority, viewed 24 March 2018, from www.social.un.org/ageingı@UN4Ageing

United Nations, 2015, World population ageing 2015. Economic and Social Affairs, United Nations, New York.

United Nations, 2016, Department of economic and social affairs, population division, World Population Ageing, United Nations, New York.

United Nations, 2017, World population ageing, United Nations Department of Economic and Social Affairs, New York.

United States Department of Agriculture, 2018, Cost of living adjustment (COLA) information, viewed 22 February 2018, from https://www.fns.usda.gov/snap/ cost-living-adjustment-cola-information

Uzoh, B.C. \& Anekwe, S.C., 2018, 'The contributory pension scheme and the fate of retired and retiring Nigerian workers', International Journal of Academic Research
in Business and Social Sciences 8(3), 527-541. https://doi.org/10.6007/IJARBSS/ in Business
$\mathrm{v} 8-\mathrm{i} 3 / 3947$

Van der Berg, S., Siebrits, K. \& Lekezwa, B., 2011, Efficiency and equity effects of socia grants in South Africa, Stellenbosch Economic Working Papers 15/10, Stellenbosch grants in South Africa, Stellenbosch Economic Working Papers

Van Zyl, E., 2003, 'Old age pensions in South Africa', International Social Security Review 56, 101-120. https://doi.org/10.1111/1468-246X.00172

World Bank, 1994, Averting the old age crisis: Policies to protect the old and promote growth, Oxford University Press, New York.

World Health Organization, 2017, World population prospects: The 2017 revision, United Nations Department of Economic and Social Affairs, New York. 